\title{
Bonobo Food Items, Food Availability and Bonobo Distribution in the Lake Tumba Swampy Forests, Democratic Republic of Congo
}

\author{
Bila-Isia Inogwabini* ${ }^{1,2}$ and Bewa Matungila ${ }^{2}$
}

\author{
${ }^{I}$ Durrell Institute for Conservation and Ecology, University of Kent, UK; ${ }^{2}$ World Wide Fund for Nature, DRC Program
}

\begin{abstract}
Data on food items were collected from the Lac Tumba Swampy Forests (LTSF) with the objective to gauge the effect of food type and availability on the distribution of the bonobos. Bonobos at the LTSF feed on at least 61 plant species and eat more Terrestrial Herbaceous Vegetation (THV) than at other sites $(\mathrm{t}=0.676, \mathrm{df}=3, \mathrm{p}=0.548>0.05$; insignificant). Fruits were available for most of the year at sites within the LTSF. At the Mbou-Mon-Tour (MMT), a site with higher bonobo density, the mean density of 1.42 fruits $/ \mathrm{m}^{2}$ per month (range $0.62-3.82$ fruits $/ \mathrm{m}^{2}$ per month) was recorded, higher than in other sites where bonobos occur (general univariate linear model $\beta=0.422, \mathrm{t}=1.543, \mathrm{df}=11, \mathrm{p}=$ 0.151, non-significant). In-site differences between MMT and other sub-sites in the LTSF were significant $(\mathrm{t}=2.793, \mathrm{df}=$ $12, \mathrm{p}=0.016<0.05)$. Fruit abundance in the LTSF $(X=138$ fruits $/ \mathrm{km}, \mathrm{SD}=13.80)$ was higher than in the Salonga National Park (SNP) ( $X=83$ fruits/km, SD = 6.49). There were five species of THV in the LTSF, with the most abundant being Megaphrynium macrostachyum (41.18\%), which was scarce in the Lomako Forests. Comparisons between sites indicated that sites in SNP consistently had lower stem densities than sites in LTSF ( $\mathrm{t}=-7.528$, df $=3, \mathrm{p}=0.005$, significant). These results, in agreement with previous studies, concluded that the distribution of THV in different sites significantly determined the bonobo distribution.
\end{abstract}

\section{INTRODUCTION}

Feeding is the most important life requirement for living organisms and particularly for large mammals. Food type and availability affect group size in large mammals, as well as sociability [1,2] and group dynamics in primates [3]. They can even affect physical morphology, as in primates where food type has been documented to influence the size and morphology of mastication muscles [4, 5], which are adapted to processing specialized items. The role that food types, food quantities and food availability play is so important in mammals that it may have played a key role in the evolution of humans [4]. In many ecological studies of wild large mammals, food availability has been proposed as one of the most important factors influencing wildlife species distribution, and is seen as vital for the great apes [6-10]. In bonobos, the food social paradigm suggests that access to food and its possession may explain the dominant role of mature females in their social organization [11]. It has been also suggested that food availability, particularly the distribution of the Marantaceae correlated with the distribution of great apes across Central Africa. Therefore, this study has two essential objectives, of which the first is to describe food types, food abundance and availability for the newly described, the westernmost and the most abundant population (mean density $=2.2$ individuals $/ \mathrm{km}^{2}$ ) of bonobos in their natural range found in the Lake Tumba Swampy Forests (LTSF). Second, the paper uses comparable food data from other sites harboring different bonobo density estimates to test the hypothesis that diversity, abundance and availability of food influence the distribution and abundance of great

*Address correspondence to this author at the Durrell Institute for Conservation and Ecology, University of Kent, UK; Tel: +243 81247 2933;

E-mail: bi4@kent.ac.uk apes in their respective ranges. Sites whose data were compared to the data from this study are the Salonga National Park (SNP) and the Lomako Forest (LF), where most recent estimates ranged within the margins of $0.24-1.8$ individuals $/ \mathrm{km}^{2}$. By focusing on the comparative analysis of effects of food on the bonobo distribution, the paper presents attempts to provide the answer to the question what determines the distribution of great apes in their respective ranges, which is one of the most important primatological questions.

\section{BONOBOS, STUDY SITES AND HABITATS}

With Gorillas (Gorilla gorilla Savage \& Wyman 1847) and Chimpanzees (Pan troglodytes Blumenbach 1775), bonobos (Pan paniscus Schwarz 1929) are one of the three species of great apes residing in Africa and the most recently described great ape [12-18]. Known historically as the dwarf chimpanzee [12, 14, 15], because of its comparatively slender physical stature, bonobos are patchily distributed, and their range is confined within the Democratic Republic of Congo (DRC), in the southern bend of the Congo River and limited further south by the Kwango-Kasai-Sankuru rivers system (Fig. 1) [14-16,19-23].

Habitats in four of the six permanent study sites (Fig. 1; Lomako, Wamba, Etate, Luikotal) are generally described as mature undisturbed forest [17, 24], with hydromorphous forest, semi-deciduous forest and islands of evergreen forest $[25,26]$. Little fragmentation had occurred therein and human densities remain very low. The two other sites (Fig. 1; Lukuru and Southern Lac Tumba) are predominantly forestsavannah mosaics. Lukuru is located in a drier savannahdominated zone and the southern Lac Tumba is mostly terra firma islands within swampy forest [27]. 


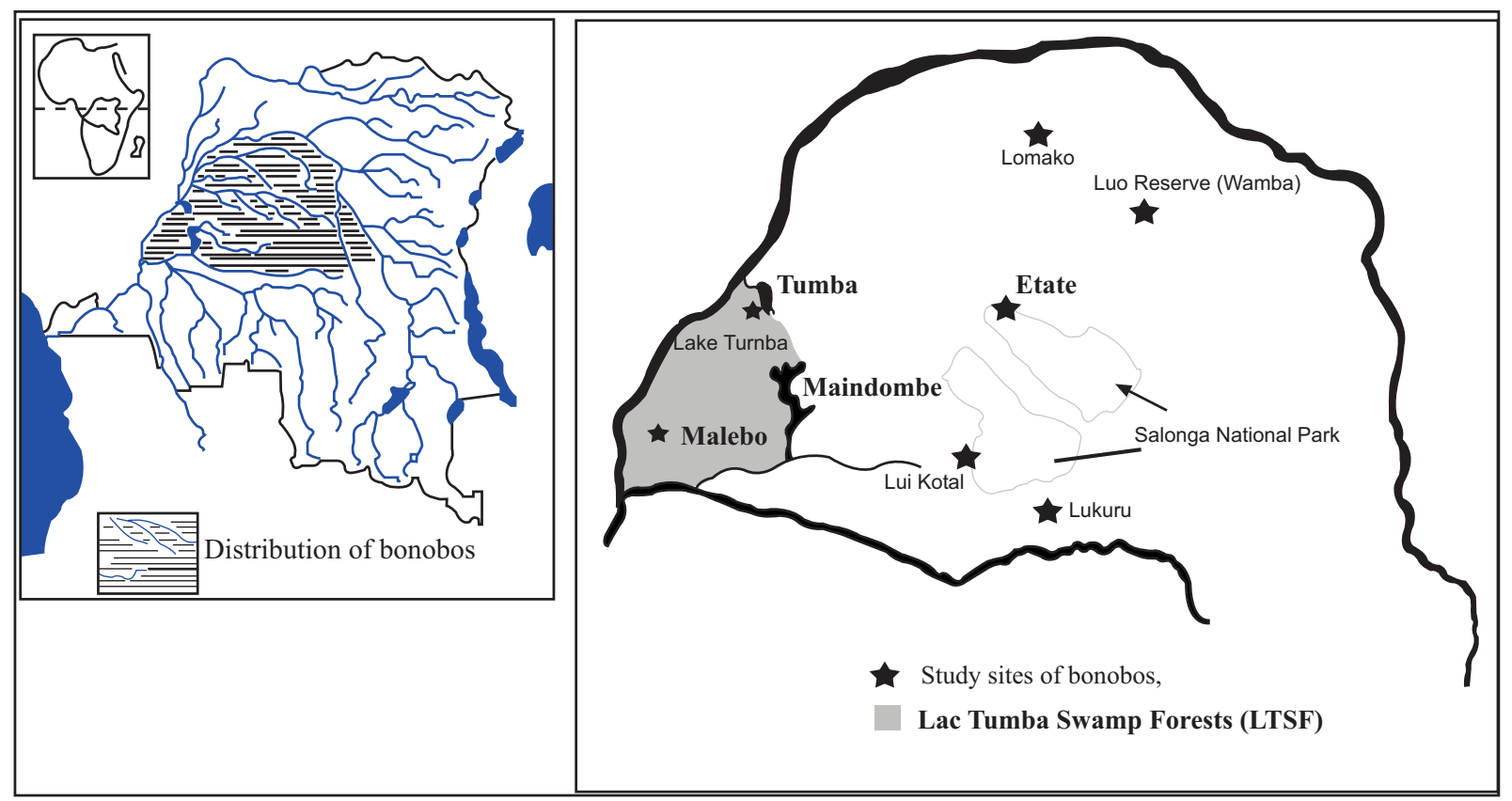

Fig. (1). Known distribution of bonobos in the Democratic Republic of Congo and locations of the 6 permanent study sites whose data are being compared in the paper.

\section{METHODS}

\section{Foods Consumed by Bonobos in the LTSF}

The first and straightforward method was to record all bonobo feeding remains (fruit, stems, insects or meat/bones) along transects and along forest reconnaissance trails. The following data were recorded: plant species, part eaten (leaf, fruit, stem, flower or root), species of insects and animal eaten (part). Each sighting of feeding remains was counted as one record (or event), regardless of the quantity found on the ground.

The second method was collection and analysis of faecal samples, which has been used to determine food types used by great apes in other sites in Central Africa [6, 7, 28, 29]. Following Fay [28], Nishihara [29] and Tutin and Fernandez [7], faecal samples were systematically searched for, located, collected, washed in a $1 \mathrm{~mm}$ mesh sieve and dried. The quantification of the fiber contents and other recognizable parts was done in situ [6, 7, 28, 29]. To identify some other species that were not easily recognized in situ, dried faecal samples were brought back to Kinshasa where they were analysed chemically at the Institut National de Recherche BioMedicale.

A third, though less rigorous, approach was to interview local trackers [28] focusing on their knowledge of what food bonobos eat. This approach was necessary because folk knowledge often underpins our scientific enquiries, and is sometimes the only knowledge we have from which to broaden scientific knowledge [30, 31]. Species identified through this last method complemented the list obtained from the field using direct identification of food remains, and the species list from faecal samples.

As suggested by Strauss and Corbin [32], Russell and Harshbarger [33], and Fay [28], precautions were taken to triangulate the recorded information from the interviews to guarantee its scientific objectivity. Triangulation was done through structured interviews, whereby the field trackers listed plants they knew bonobos ate in their region using local names. Then, in several villages, other local hunters were asked to verify whether they knew that these species were eaten (or not) by the bonobos. At the end of the interviews, local hunters were asked to list anything else they knew to be consumed by bonobos but had been omitted from the list.

Analytically, numbers of food remains by distance traveled was used to quantify the relative consumption index of each species utilized by bonobos across the region. Then, the ten most frequently consumed species, i.e. the ten species with the highest consumption indices, were used for other analyses described below.

\section{Fruit Fall Phenology}

Data on fruit availability were collected using two methods: the first was to conduct fruit fall phenology [34-40]. Permanent $4 \mathrm{~m}^{2}$ plots were established in three different areas and were visited twice a month to count all fruits found therein. The three sites were: Mbou-Mon-Tour (MMT, at Nkala), Mpelu and Edzaengo. The first site is an area with a higher bonobo density, the second has a moderate density but bonobos live there permanently, while bonobos only visited the last site during some periods of the year. Nest counts indicated that bonobos visited Edzaengo in lower numbers. To see how long fruit was available in the LTSF, fruit data were collected for one year and were correlated with a 1-year weather data set to see if variations in seasonal patterns affected the availability of fruits in the study site.

The second method (to obtain comparable data with the SNP where fruit data collected in 2003) was adapted from Blake [41]. Accordingly, each observation of fallen fruit along transects was noted as: very abundant, abundant, few and rare. Because this provided no quantitative measures of abundance, the second step was to count fruits in plots to 
quantify the definition of observers for each category: very abundant, abundant, few and rare. To compare fruit in the SNP and LTSF we ran a linear regression on fruit numbers per category to see if they correlated. As there was a significant correlation coefficient $\left(R^{2}=0.7034\right)$, we then used the correlation equation $(y=6.1137 x-6.0803)$ to calculate number of fruits per category for the SNP, which were compared with fruit records in the LTSF using the encounter rates of each site (Fig. 6a). Comparing categorical data with quantitative data has been used in other studies such as Walsh and White [42], Walsh et al. [43], Walsh et al. [44] and Takenoshita and Yamagiwa [45] wherein categorical data on encounter rates were used to project expected quantitative abundances through regression analysis. To avoid problems with observer bias, we had an observer who collected data in the SNP collect the same data in the LTSF. Equally, to avoid the effect of seasons on both sets of data, we have compared only data from the SNP that were collected in the month of May 2003 and those of May and early June 2006 in the LTSF.

\section{Herbaceous Plant Availability: Stem Counts}

The quantification of herbaceous vegetation used as food by bonobos followed Fay [28], White et al. [46, 47], Williamson [8], and Rogers and Williamson [9], using $4 \mathrm{~m}^{2}$ plots from which all live stems of herbaceous vegetation were counted. Only stems that had roots in the sampling plots were counted. The stem count was carried out in four different sites in the LTSF (MMT, Mpelu, Edzaengo and Tsieli). As indicated above, these sites harbored different bonobo density estimates, and so allowed comparisons between sites to see if the abundance of terrestrial herbaceous vegetation influenced the distribution of bonobos. Similar data were also collected in the SNP, including areas that are completely devoid of any bonobos. We used the SNP set of data for comparison. The abundance of herbaceous vegetation was calculated from simple densities (number of stems $/ \mathrm{m}^{2}$ ), and these densities were used for comparison between different sites in the LTSF, and between LTSF and other sites, principally the SNP.

To see if there were significant differences of stem density per species and per site within the LTSF area, the four sites were compared using a step-wise two-tailed and twosample equal variance T-test. The same test was used to test for differences between sites in the SNP and those in the LTSF. The Jaccard binary coefficient $J$ was calculated to quantify the overlap [48] in species diversities between the LTSF and other sites where comparable data were available. The value of $\mathrm{J}$ was obtained from the formula

$$
\mathrm{J}=\frac{a}{a+b+c}
$$

In this formula, $J$ is the similarity coefficient expressed in $\%$ overlap [49]; $a$ is the number of species common to the 2 samples being compared; $b$ is the number of species found in the first sample only, while $c$ is the number of species found in the second sample only, as indicated by the Vein diagram of Fig. (2). $J$ plays exactly the same role as the Soerenson similarity index [50], which is expressed in $\%$ and because of that, higher values indicate higher resemblance, with a complete overlap having the value $100 \%$.

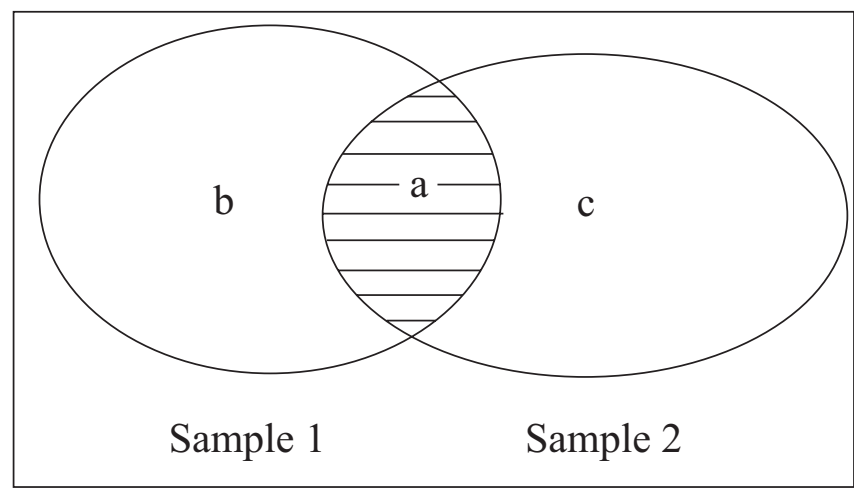

Fig. (2). The Vein Diagram showing the method of calculation for the similarity coefficient $\mathrm{J}$.

This method was also used to evaluate the overlap between the information provided by local communities on food items, and that from field observations of food remains and faecal samples.

\section{RESULTS}

\section{Food Consumed by Bonobos in the LTSF}

The inventory of food items obtained by direct observations and from food remains indicated that bonobos fed on 39 plant species. When the information provided by local communities was added, bonobos at the LTSF feed on at least 61 plant species. Obviously, different methods provided a different number of plant species, with the information from local communities providing the most $(\approx 67 \%)$, followed by that from food remains $(\approx 53 \%$; Fig. 3). The overlap coefficient was $\mathrm{J}=15 \%$ between all methods, but there was a larger coefficient of overlap between the results from food remains and the local community food list $(\mathrm{J}=30.1 \%)$, and between plant species in food remains and faecal samples $(\mathrm{J}=30 \%)$. Results from interviews with local communities at the south-westernmost edge of the study site indicated that food items included some species cultivated by humans, such as sugar cane (Saccharum officinarum), banana (Musa paradisiaca), maize (Zea mays), papaya (Carica papaya), pineapple (Ananas sativus), sweet potatoes (Ipomea spp) and cocoa (Theobroma cacao).

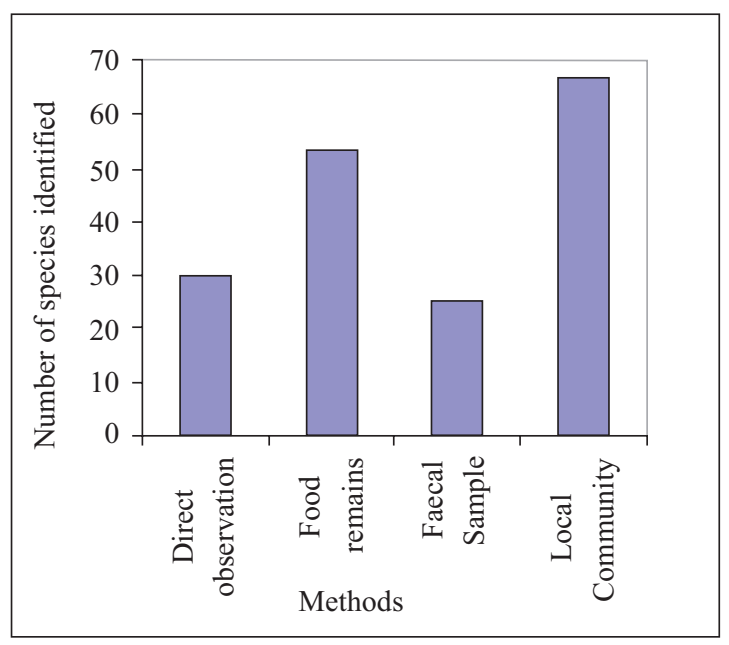

Fig. (3). \% Information on food items provided by different research methods. 


\section{Plant Parts Eaten by Bonobos}

Fruit represented ca. $42 \%$ of the fresh and recent food remains $(\mathrm{N}=1289)$, while THV represented $48 \%$ (including young leaves and young shoots). Piths and flowers accounted for the remaining $10 \%$ (ca. 1\% and ca. 9\% respectively). When compared to overall means from other sites (Conklin-Britain et al. 2001; Fig. 4), bonobos at the LTSF ate more THV than the mean from other sites. A paired sample T-test indicated, however, that the difference was not statistically significant $(t=0.676, d f=3, p=0.548>0.05)$.

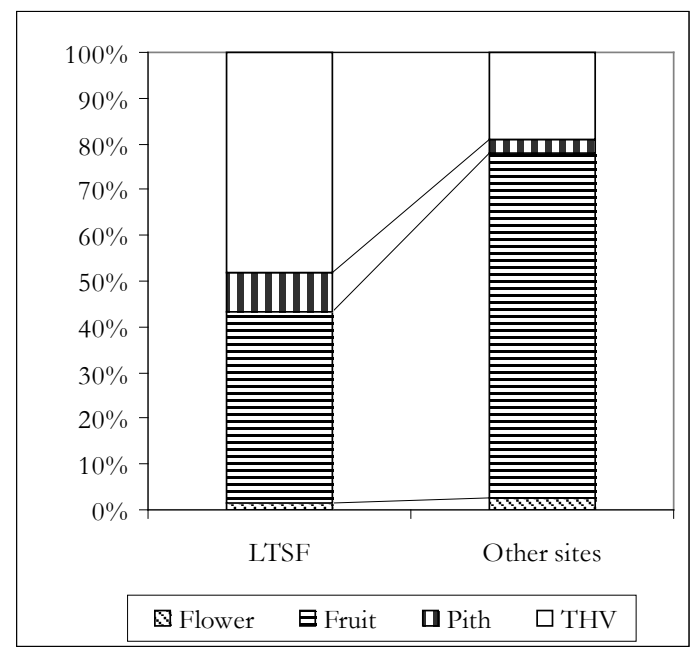

Fig. (4). \% Plant parts eaten compared between LTSF and overall mean from three other sites (Lomako, Wamba and Yalosidi) (Conklin-Britain et al. 2001).

\section{FOOD ABUNDANCE}

\section{Fruit Fall Phenology}

Fruits were available for most of the year at all three sites but in different quantities (Fig. 5). At the MMT site there was a mean density of 1.42 fruits $/ \mathrm{m}^{2}$ per month (range 0.62 3.82 fruits $/ \mathrm{m}^{2}$ per month). A general linear model test (uni- variate), with seasons as the independent variable, showed that there was no significant variation across the year $(\beta=$ $0.422, \mathrm{t}=1.543, \mathrm{df}=11, \mathrm{p}=0.151)$. However, there were two peaks in fruit availability in the study site, the first at the end of April (3.56 fruits $/ \mathrm{m}^{2}$ ) and throughout the month of May (3.82 fruits $/ \mathrm{m}^{2}$ ), while the second peak was in December $\left(2.36\right.$ fruits $/ \mathrm{m}^{2}$ ) (Fig. 5). The same statistical test indicated that fruit fall patterns in Mpelu also did not vary significantly across the year $(\beta=214, \mathrm{t}=0.727, \mathrm{p}=0.482>$ $0.05)$.

Internal differences within sub-sites in the LTSF were significant between MMT and the rest of the zone; paired Ttests of fruit fall patterns between MMT and both Mpelu and Adzaengo were significantly different $(\mathrm{t}=2.793$, df $=12, \mathrm{p}$ $=0.016<0.05 ; \mathrm{t}=2.538, \mathrm{df}=12, \mathrm{p}=0.026<0.05$, respectively). The difference between Mpelu and Edzaengo was non-significant $(\mathrm{t}=1.067, \mathrm{df}=12, \mathrm{p}=0.307)$. Edzaengo, a site with a lower encounter rate of bonobo signs, had less fruit throughout the year than any other site in the region. Peak months were within rainy seasons, which suggests that fruit was more abundant during the rainy seasons, but more fruits were available during the minor rainy season from March - May, though differences between the two rainy seasons were statistically insignificant.

\section{Comparison of Fruit Abundance Between SNP and LTSF}

The correlation coefficient $\left(\mathrm{R}^{2}=0.7034, \mathrm{df}=31\right)$ between fruit abundance and categorical qualitative estimates of abundance was significant (Fig. 6a). Therefore the equation $\mathrm{y}=6.1137 \mathrm{x}-6.0803$ was used to estimate relative fruit abundance in the SNP. Comparison of relative fruit abundance showed that there was more fruit available in the LTSF ( $X=138$ fruits $/ \mathrm{km}, \mathrm{SD}=13.80$ ) than in the SNP ( $X=83$ fruits $/ \mathrm{km}, \mathrm{SD}=6.49$ ) (Fig. 6b).

\section{Terrestrial Herbaceous Vegetation (THV) Availability}

Stems of terrestrial herbaceous vegetation were counted in 26 plots at MMT and 25 plots at Mpelu, Edzaengo and

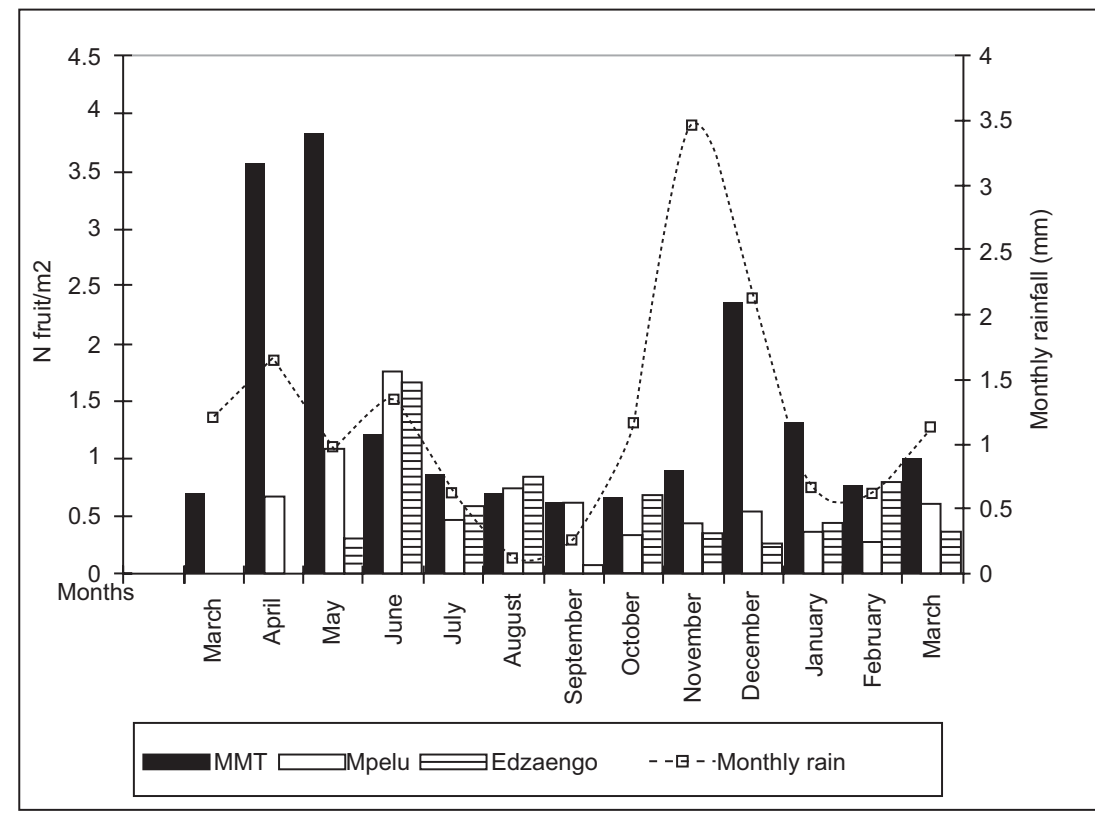

Fig. (5). Fruit fall and Rainfall in the LTSF. 


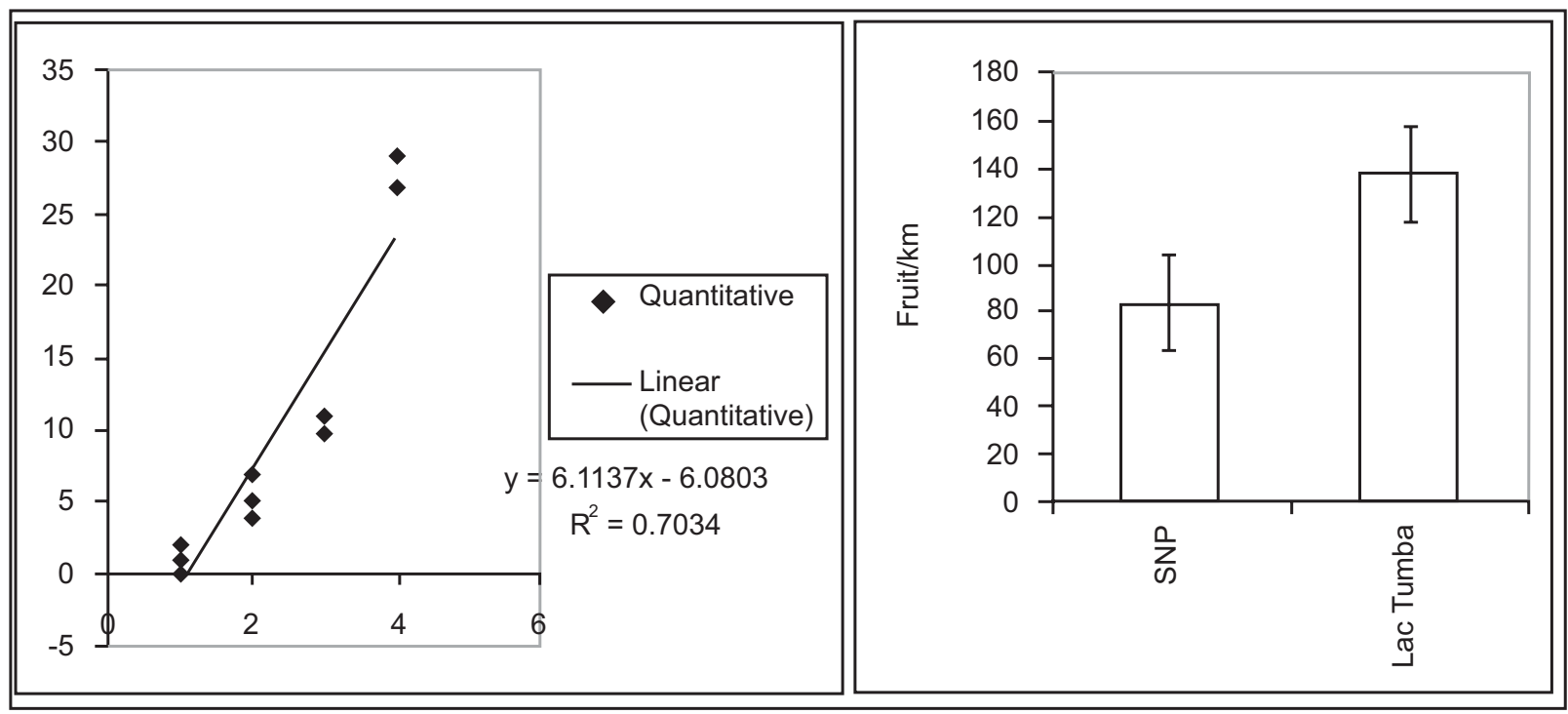

Fig. (6). (a) Linear regression of fruit abundance category and fruit numbers; (b) relative fruit abundance compared between the SNP and LTSF.

Tsieli for each location, making a total of 101 plots or $404 \mathrm{~m}^{2}$. The overall stem density was $10.81 \mathrm{stems} / \mathrm{m}^{2}$ at MMT, higher than in the remaining sites where stem densities varied between 8.78 stems $/ \mathrm{m}^{2}$ and 8.03 stems $/ \mathrm{m}^{2}$ (Table 1). Results of pairwise comparisons using step-wise twotailed and two-sample equal variance T-test are in Table 2. All pair-wise tests had $\mathrm{df}=3$ and had significant levels that were below the expected p-value at 0.05 , indicating that the spread of terrestrial herbaceous vegetation was significantly different across the four sites.

\section{THV: Comparison Between the SNP, LTSF and LF}

In the SNP stems were counted in 56 plots of $3 \mathrm{~m} \times 3 \mathrm{~m}$ $\left(9 \mathrm{~m}^{2}\right)$ across different forest types, making a total area of 504 $\mathrm{m}^{2}$. Comparing the THV density in the SNP and the density from the LTSF, the mean density of stems $\left(4.11 \mathrm{stems} / \mathrm{m}^{2}\right)$ in the SNP is lower than in the LTSF; it is even less than $50 \%$ of the value obtained from the LTSF (9.08 stems $/ \mathrm{m}^{2}$, Fig. 7). A pair-wise comparison between sites in these two landscapes also indicated clearly that sites in the SNP consistently had lower stem densities than sites in LTSF (Fig. 7b). The overall difference was statistically significant $(\mathrm{t}=$ 7.528 , df $=3, p=0.005)$. The striking result that emerged from this data set was that for the SNP, known local densities of bonobos do not correlate with the distribution of terrestrial herbaceous vegetation. In fact, Bekongo where there was a higher density of stems was a site where bonobos have never been observed in the recent past, while the other three sites (Beminyo, Lokofa, and Yongo) were sites where bonobos occurred in relatively higher densities [51].

Table 1. Stem Densities in the 4 Sites within the LTSF

\begin{tabular}{|c|c|c|c|c|c|c|c|c|c|c|c|c|}
\hline \multirow{2}{*}{$\begin{array}{c}\text { Site } \\
\text { Species }\end{array}$} & \multicolumn{3}{|c|}{ MMT } & \multicolumn{3}{|c|}{ Mpelu } & \multicolumn{3}{|c|}{ Edzaengo } & \multicolumn{3}{|c|}{ Tsieli } \\
\hline & $\mathbf{N}$ & $\mathbf{M}^{2}$ & Density & $\mathbf{N}$ & $\mathbf{M}^{2}$ & Density & $\mathbf{N}$ & $\mathbf{m}^{2}$ & Density & $\mathbf{N}$ & $\mathbf{M}^{2}$ & Density \\
\hline Aframomum & 25 & 104 & 0.24 & 2 & 100 & 0.02 & 13 & 100 & 0.13 & 2 & 100 & 0.02 \\
\hline Haumania liebrechtsiana & 424 & 104 & 4.08 & 456 & 100 & 4.56 & 173 & 100 & 1.73 & 456 & 100 & 4.56 \\
\hline Megaphrynium Sp. & 506 & 104 & 4.87 & 340 & 100 & 3.40 & 444 & 100 & 4.44 & 340 & 100 & 3.40 \\
\hline Palisota ambigua & 169 & 104 & 1.63 & 80 & 100 & 0.80 & 187 & 100 & 1.87 & 80 & 100 & 0.80 \\
\hline Renealmia & 0 & 104 & 0.00 & 0 & 100 & 0.00 & 47 & 100 & 0.47 & 0 & 100 & 0.00 \\
\hline Overall Species & 1124 & 104 & 10.81 & 878 & 100 & 8.78 & 864 & 100 & 8.64 & 803 & 100 & 8.03 \\
\hline
\end{tabular}

Table 2. t-Values for Pairwise Comparisons Between Sites within the LTSF

\begin{tabular}{|c|c|c|c|c|}
\hline Site/site & MMT & Mpelu & Edzaengo & Tsieli \\
\hline \hline MMT & ---- & 0.74781 & 0.65158 & 0.74781 \\
\hline Mpelu & 0.74781 & ---1.0000 \\
\hline Edzaengo & 0.65158 & 0.91634 & 0.91634 & 0.91634 \\
\hline Tsieli & 0.74781 & 1.0000 & ----- & - \\
\hline
\end{tabular}




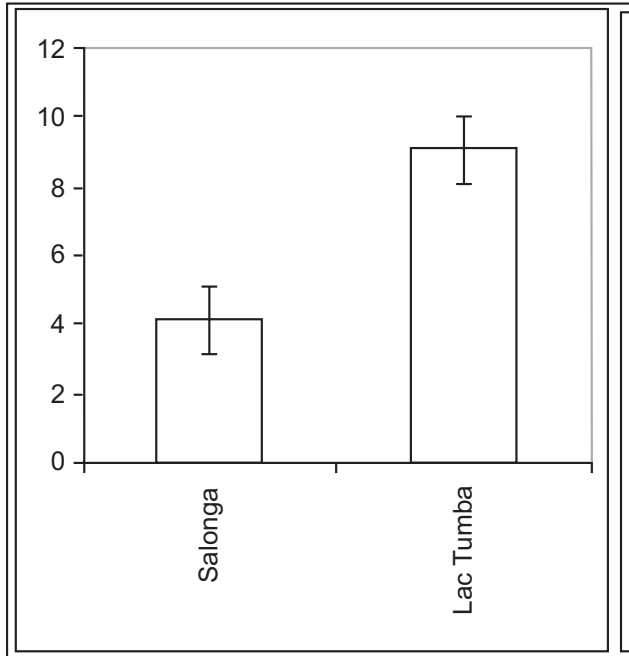

(a) Overall stems $/ \mathrm{m}^{2}$

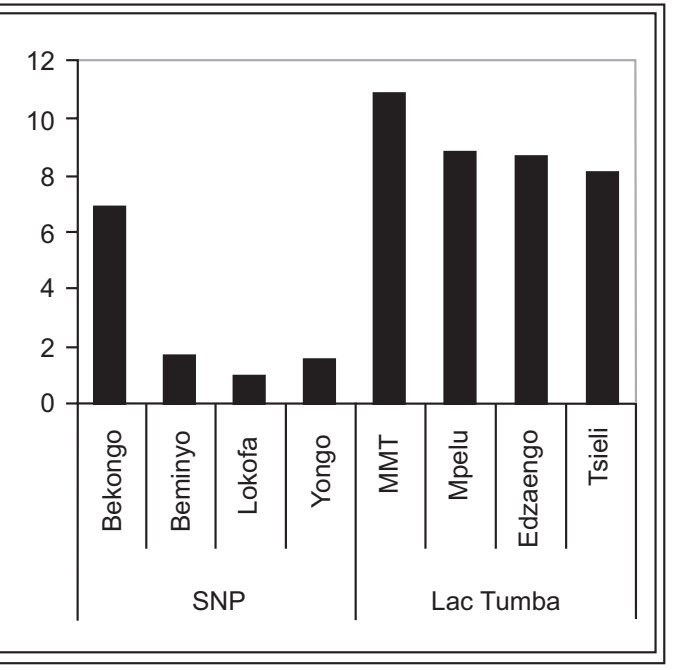

(b) Site by site comparison

Fig. (7). mean stems $/ \mathrm{m}^{2}$ compared between SNP and LTSF.

There were five species present in plots used for stem counts in the LTSF. The most abundant was Megaphrynium macrostachyum (41.18\%; N =3669), followed by Haumania liebrechtsiana (32.13\%) and Palisota ambigua (23.08\%) (Fig. 8). Re-analysis of the THV data from LF [52] indicated that the most common species was Haumania liebrechtsiana (41\%), followed by Palisota ambigua (35.7\%) and Trachyphrynium braunianum (11\%). Some species sampled in Lomako were absent in the LTSF and vice versa: Aframomum spp. and Megaphrynium macrostachyum were not present in the LF sample plots, while Trachyphryium braunianum and Sarcophrynium schweinfurthii were not counted in the LTSF. The most remarkable result here was the paucity at Lomako of the most conspicuous species of THV (Megaphrynium macrostachyum) recorded at LTSF. Despite that remarkable absence however, the $\chi^{2}$ test for difference indicated no significant difference between the two sites with regard to the diversity of THV $\left(\chi^{2}=0.750, \mathrm{df}=6\right.$, $\mathrm{p}=0.993>0.05$ ). The Jaccard similarity coefficient was $\mathrm{J}=$ 0.42 , indicating that species-wise the two sites shared $42 \%$.

\section{DISCUSSION}

Food plays a key role in sustaining the life of large mammals [53, 54]. Therefore, identifying food items and their availability and distribution throughout the habitat is critical for habitat management of different wildlife species [54]; and food distribution has been studied as a surrogate for species distribution in many instances [55].

Available knowledge on feeding ecology of bonobos from different sites [56] revealed wide variations in numbers of plant species consumed by bonobos. The numbers of plant species consumed by bonobos range from over a dozen [18, 57] to more than a hundred species [58]. Available data indicated that the study site where bonobos consumed most plant species was Wamba (Fig. 1), with 142 plant species con-

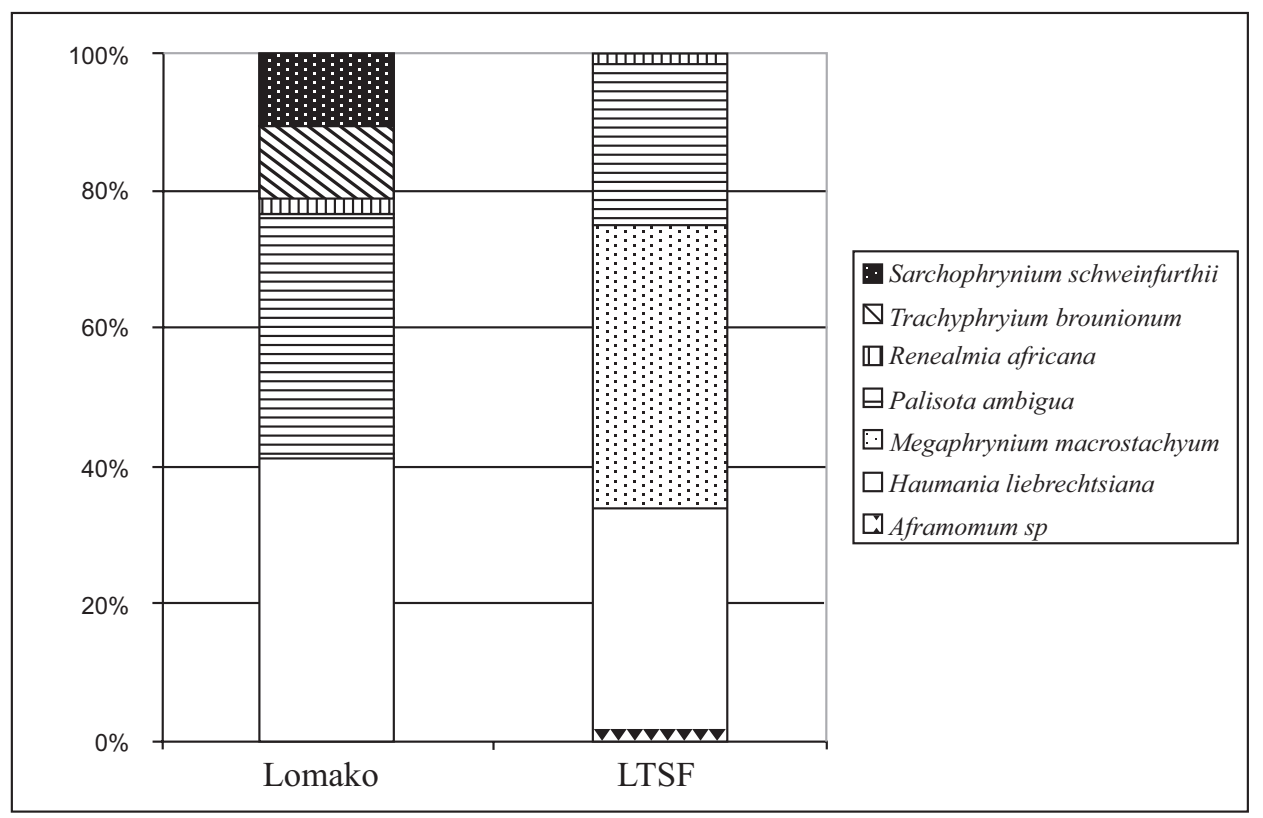

Fig. (8). THV diversity compared between LTSF and Lomako. 
sumed [58]. At LF (Fig. 1), bonobos consumed 81 plant species [24], while 34 plant food items were identified for bonobos at Yalosidi [59]. For the LTSF (Fig. 1), a previous study by Horn $[18,57]$ found that bonobos ate 14 plant species, which is lower than the figure reported by this study, where 61 plant species were identified as food items for bonobos. However, the figure of 61 plant species consumed by bonobos in the LTSF did not deviate from the overall picture across the species range.

The difference between the results of this study and that of Horn $[18,57]$ may be due to three main reasons: the first, and probably the most important, is that Horn's study was undertaken in a very small area near Lake Tumba, which would not have been representative of the diversity of the entire landscape. The LTSF as described in this study is a much larger zone encompassing a large assemblage of microhabitats and several gradients. Microhabitats include permanent water bodies, forest-savannah mosaics, open herbaceous and woody savannahs, terra firma mixed mature forests, old logged concessions, etc. Gradients include forest strata near major rivers, and altitudinal variations ranging from flat forest ground to fringes of plateaus. Such a variety of habitats will certainly contain a variety of different plant species. Horn's study $[18,57]$ was confined to one habitat type, which offered very little palatable vegetation to bonobos. The second reason for the difference in the results of the two studies may simply reflect differences in methodologies. Horn [18, 57] assessed food items only from feeding remains, while this study combined three different sources of information beyond counting food remains. Here, information from faecal samples, local communities, and occasionally direct observations were all included. The third reason for the difference in the results of the two studies may be due to different lengths of study. Horn's study $[18,57]$ lasted one year, while this study has been ongoing for more than 24 months now, and has permanent field staff collecting data on a daily basis, which accumulates over time.

Fruits constitute a large proportion of the food consumed by great apes $[6,28,58,60]$, and particularly by bonobos $[6$, $24,61,62]$. Proportions of fruits eaten by bonobos in the LTSF $(41.87 \%)$ did not significantly differ from reports from Lomako, where fruit accounted for $45 \%$ - 63\% [17, 24, 63]. However, proportions of leaves $(7.3 \%)$ consumed in the LTSF differed significantly from the larger figure of $21 \%$ $25 \%$ from Lomako [17, 24, 63].

Fruits were available all year round, though their abundance correlated with seasonal variations. The highest densities of fruit were observed during the rainy season between April and May, followed again by another peak in December, in the longest rainy season. Despite that apparent seasonality, however, fruit was still present at any time of year and so bonobos had access to fruit all year.

Comparing the fruit abundance data from the LTSF and the data collected from the SNP (Fig. 6), there was more fruit in the LTSF than in the SNP. If food is the only factor dictating distribution $[54,55]$, this result would explain the observed difference in bonobo densities between the two sites. However, the Lomako data set, despite the fact that it was collected using different methods and was therefore not directly comparable, indicated higher abundance of fruits and their year-round availability to bonobos [64]. Yet bonobo density at Lomako remains lower than in the LTSF [27]. This contradictory picture would suggest that fruit abundance and availability alone cannot explain the differences in bonobo densities in the three sites.

A possible explanation may be that bonobos in the LTSF were observed $(\mathrm{N}=5)$ ranging through savannahs in the dry seasons, when fruits become less abundant in the forest. In the dry seasons, trees of Annoniduim senegalensis, a savannah tree species, begin fruiting, which may provide food to bonobos. A senegalensis produces a juicy succulent fruit, which would compensate for any increased time searching for food by providing sufficient energy to the bonobos at this particular time of year [65]. Ranging in the savannah may also provide other types of food that were either mentioned by local communities during interview sessions, or some of the food species documented through faecal remains. Cultivated species such as $S$. officinarum, $M$. paradisiaca, $Z$. mays, C. papaya, A. sativus, and Ipomea spp. are grown in fields located at the forest-savannah interfaces. They may offer easy food resources at the period when fruit abundance decreases in the forest. Also, the savannahs of the Malebo region are characterized by series of termite mounds that are spread over large areas. These termite mounds may produce termites in sufficient quantities to be attractive to bonobos. Analyses of faecal samples showed that bonobos at the LTSF ate termites, even though this was in negligible proportions.

One of the most interesting findings of this study is that bonobos consumed fruits in similar proportions to THV (Fig. 4). Data presented here demonstrated that fruits were available for most of the year at all three sites, even though in different quantities (Fig. 5). As stated above, fruit plays a key role in the feeding regime of the great apes $[6,24,28$, $58,60-62]$, but THV species have often been described as fall-back food resource during periods of food scarcity [6, 52]. It is striking that even with fruits present, bonobos in the LTSF continued to eat significant portions of the THV.

Terrestrial herbaceous vegetation (THV) composed of species belonging to the families Zingiberaceae and Marantaceae are known to be an important component of the diet of African great ape species, even for those that are highly frugivorous $[9,66]$. Species in these families, such as Aframomum spp., Haumania liebrechtsiana, Haumania dankelmaniana, Megaphrynium macrostachyum etc. are eaten extensively by both species of gorilla Gorilla g. gorilla and Gorilla g. berengei [9, 67-70] and chimpanzee Pan troglodytes [68, 69, 71].

For bonobos, the critical role played by THV has been documented from different field sites [56] and the availability of THV has been suggested as one of the single most important factors influencing the species distribution and behavior [6]. The key ecological role played by THV is not only attributed to the fact that THV may act as fallback food during periods of fruit shortage [4, 6, 23, 72-74], but also to their higher protein content. Biochemical analyses of THV species such as Megaphrynium macrostachyum and Haumania liebrechtsiana, consumed by bonobos, concluded that they are rich in protein [75] and therefore important nutritionally $[72,75]$.

Results from this study (Fig. 1) indicated that bonobos in the LTSF have a more balanced diet than the average from 
other sites, consuming more THV even when fruits are available. This finding implies that, at least for the bonobos in the LTSF, THV is not only important at times of fruit shortage because bonobos have been observed ingesting significant quantities of leaves, flowers, stems, pith and shoots of THV even when fruit is also available. Bonobos of the LTSF may be trying to balance their nutrition using all the food sources available to them all the time.

THV occurs widely and is a non-seasonal food source [9, 73, 76-79] for bonobos. However, THV distribution across the range is not homogenous. Stem counts done both in the SNP and the LTSF indicated that densities of THV were higher in the LTSF than in the SNP (Fig. 7). If food was the only factor explaining densities of great apes, it would be logical to infer that higher densities of bonobos in the LTSF [80] are related to the higher densities of THV stems. It has been argued in other instances that the highest bonobo density (3.4 individuals $/ \mathrm{km}^{2}$ ) reported from the LTSF is probably explainable by the forest-savannah mosaic system, which may provide year round fruit sources, bonobos falling back on savannah fruits when the forest resources are scarce [27, 80]. Suggestions were made for more in-depth ecological research to determine what factors that would explain observed difference between bonobo densities at LTSF and other sites (Fig. 1). Marantaceae species are known to be a key determinant for the distribution of great ape species across Central Africa [6, 28, 52, 75, 78], statistically significant differences in THV stems may be the driving factor for observed differences in bonobo densities across their range. THV are one stage of the forest regeneration process [81]. Forest-savannah mosaics at Malebo occur at an area where the forest dynamics is that of the re-colonization of savannah by forests, with thick THV layers bourgeoning above the ground. This provides more food to bonobos and the conclusion that forest-savannah mosaics may be a bonobo preferred habitat, while dense forest habitats may be more marginal habitats for this species [80] is but a surrogate to concluding that more THV provided by the forest-savannah environment provide better conditions for bonobos to increase in numbers. The problem with this conclusion is that at Bekongo, the site in the SNP where we found relatively higher stem densities was a site where bonobos have never been reported. Therefore, the distribution of THV may be only one of the factors influencing bonobo distribution. It could be that fruit availability during most of the year, combined with higher densities of THV, would explain the differences in bonobo densities.

It is of conservation importance to note that plant items cited by local communities included food staples cultivated by humans. Bonobos have been observed in fields consuming these items, particularly bananas, sugar cane, papayas and sweet potatoes. The implications of this finding range from eventual human-bonobo conflict to helping zoos that have bonobos in captivity to find suitable food for them. Of particular interest is the story from the local communities about how bonobos uproot sweet potatoes from the ground. The story goes that bonobos use sticks to dig out the sweet potatoes. Throughout this study, efforts were made to observe this, without success, because the behavior may shed some more light on bonobo culture, particularly tool use. Hopefully on-going ecological studies at the LTSF will uncover the way bonobos extract potatoes from the ground.

\section{ACKNOWLEDGEMENT}

This work has been partially funded by the USAIDCARPE. However views expressed by the authors do not reflect those of the USAID. As part of a $\mathrm{PhD}$ thesis, the study has been designed at the Durrell Institute for Conservation and Ecology, the University Kent at Canterbury, UK under the supervision of Professor Nigel Leader-Williams. Dr Elizabeth Rogers, Dr Elizabeth Williamson and Dr Jo Thompson helped improve the quality of early drafts. Data from the SNP were collected while the first author worked with the Zoological Society of Milwaukee. We are the most thankful to the WWF US for its permission to use the data, WWF DRC for helping with the necessary official documents to carry out field research in Lac Tumba landscape.

\section{REFERENCES}

[1] White JF. Ecological correlates of pygmy chimpanzee social structure. In: Standen V, Foley RA, Eds. Comparative socioecology: the behavioural ecology of humans and other mammals. Oxford: Blackwell Scientific Publications 1989; pp. 151-64.

[2] Thompson-Handler N, Malenky RK, Badrian NL. Sexual behavior of Pan paniscus under natural conditions in the Lomako forest, Equateur, Zaïre. In: Susman RL, Ed. The pygmy chimpanzee: Evolution biology and behavior; New York: Plenum Press 1984; pp. 347-68.

[3] Anderson DP, Nordheim EV, Boesch C, Moermomd TC. Factors influencing fission-fusion grouping in chimpanzees in the Taï National Park, Côte d'Ivoire. In: Boesch C, Hohmann G, Marchant LF, Eds.; Behavioural diversity in chimpanzees and bonobos, Cambridge: Cambridge University Press 2002; pp. 90-101.

[4] Laden G, Wrangham R. The rise of the hominids as an adaptive shift in fallback foods: Plant underground storage organs (USOs) and australopith origins. J Hum Evol 2005; 49: 482-98.

[5] Elgart-berry A. Fracture Toughness of Mountain Gorilla (Gorilla gorilla beringei) food plants. Am J Primat 2004; 62: 275-85.

[6] Malenky RK, Wrangham RW. The relative importance of terrestrial herbs for bonobos and chimpanzees: comparative data from Lomako and Kibale. Bull Chicago Acad Sci 1994; 15 : 7.

[7] Tutin CEG, Fernandez M. Composition of the diet of chimpanzees and comparisons with that of sympatric lowland gorillas in the Lope Reserve, Gabon. Am J Primat 1993; 30: 195-11.

[8] Williamson EA. The behaviour ecology of western lowland gorillas. Ph.D. Thesis. University of Stirling. Stirling: United Kingdom 1988.

[9] Rogers ME, Williamson EA. Density of herbaceous plants eaten by gorillas in Gabon, some preliminary data. Biotropica 1987; 19: 278-81.

[10] White JF. Behavioral ecology of the pygmy chimpanzee. PhD. Thesis, State University of New York, USA: Stony Brook 1986.

[11] White FJ, Wood K.D. Female feeding priority in Bonobos, pan paniscus, and the question of female dominance. Am J Primat 2007; 69: 1-14.

[12] De Waal F, Lanting F. Bonobo: The forgotten ape. Berkeley: University of California Press 1997.

[13] Kempf E, Wilson A. Les grands singes dans la nature-Rapport du World Wide Fund for Nature sur le statut des espèces. World Wide Fund for Nature Gland: Switzerland 1997.

[14] Kingdon J. The Kingdon Field Guide to African Mammals. San Diego: Academic Press 1997.

[15] Thompson JAM. The history, taxonomy and ecology of the bonobo (Pan paniscus Schwarz 1929) with a first description of a wild population living in a forest/savanna mosaic habitat. Ph.D. Thesis. Oxford University, Oxford: United Kingdom 1997.

[16] Thompson-Handler N, Malenky RK, Reinartz G. Action plan for pan paniscus: report on free ranging populations and proposals for their preservation, Zoological Society of Milwaukee County, Milwaukee 1995.

[17] Badrian NL, Badrian AJ, Susman LR. Preliminary observations on feeding behaviour of Pan paniscus in the Lomako Forest of Central Zaire. Primates 1982; 22(2): 173-81. 
[18] Horn AD. Some observations on the ecology of the bonobo chimpanzee (Pan paniscus Schwarz 1929) near Lake Tumba, Zaire. Folia Primatol 1980; 34: 145-69.

[19] Thompson JAM. Bonobos of the Lukuru Wildlife Research Project. In: Boesch C, Hohmann G, Marchant LF, Eds. Behavioural diversity in chimpanzees and bonobos. Cambridge: Cambridge University Press 2002; pp. 61-70.

[20] Reinartz GE, Inogwabini BI. Bonobo survival and the wartime mandate. In The Great Apes: Challenges for the $21^{\text {st }}$ Century. Conference proceedings. Chicago: Brookfield Zoo 2001; pp. 52-6.

[21] Kortlandt A. A survey of the geographical range, habitats and conservation of the Pygmy chimpanzee (Pan paniscus): Ecological perspective. Prim Conserv 1995; 16: 21-36.

[22] Malenky RK, Thompson-Handler N, Susman RL. Conservation status of Pan paniscus. In: Heltne PG, Marquardt LA, Eds. Understanding chimpanzees, Cambridge \& London: Harvard University Press 1989; pp. 362-368.

[23] Kano T. Distribution of Pygmy chimpanzees (Pan paniscus) in the Central Zaire Basin. Folia Primatol 1984; 43: 36-52.

[24] Badrian NL, Malenky RK. Feeding Ecology of Pan paniscus in the Lomako forest, Zaire. In the pygmy chimpanzee: evolutionary biology and behavior, Susman RL, Ed.; New York: Plenum Press 1984; pp. 325-46.

[25] Evrard C. Cadre biogéographique du Parc National de la Salonga. In Premier Séminaire International sur la gestion et l'avenir du Parc National de la Salonga; Département des affaires foncières, environnement et conservation de la nature, Ed. United Nations Education, Science and Culture Organization (UNESCO): Paris 1987; pp. 43-48.

[26] Evrard C. Recherches écologiques sur le peuplement forestier de sol hydromorphe de la Cuvette Centrale congolaise. Office National de la Recherche pour le Développement (ONRD)/ L'Institut National Pour L'Étude Agronomique du Congo (INEAC)-Ministère Belge de l'éducation et de la culture. Bruxelles 1958.

[27] Inogwabini BI, Matungila B, Mbende L, Abokome M, Miezi V. The Bonobos of the Lake Tumba-Lake Maindombe Hinterland: Threats and Opportunities for Population Conservation. In Furuichi T, Thompson J, Eds. The Bonobos: Behavior, Ecology, and Conservation. New York: Springer 2007; pp. 273-90.

[28] Fay JM. The ecology, social organization, population, habitat and history of the western lowland gorilla (Gorilla gorilla gorilla Savage \& Wyman, 1947). Ph.D. thesis. Washington University, United States of America 1997.

[29] Nishihara T. Feeding ecology of Western Lowland Gorillas in the Nouabalé-Ndoki National Park, Congo. Primates 1995; 36(2): 15168.

[30] Vansina J. Paths in the rainforests-toward a history of political tradition in equatorial Africa. University of Wisconsin Press: Madison 1990.

[31] Myers N. The primary source-the tropical forests and our future. United Kingdom: Longman 1985.

[32] Strauss A, Corbin J. Basics of qualitative research-Techniques and procedures for developing a grounded theory. Newbury: Sage Publications 2007.

[33] Russell D, Harshbarger C. Ground Work for Community Based Conservation. Walnut Creek, California: AltaMira Press 2004.

[34] Takenoshita Y, Ando C, Iwata Y, Yamgiwa J. Fruit phenology of the great ape habitat in the Moukala-Doudou National Park, Gabon. Afr Stud Monogr Suppl 2008; 39: 23-39.

[35] Yamagiwa J, Basabose AK, Kaleme KP, Yumoto T. Phenology of fruits consumed by sympatric population of gorillas and chimpanzees in Kahuzi-Biega National Park, Democratic Republic of Congo. Afr Stud Monogr Suppl 2008; 39: 3-22.

[36] Barlow J, Overal W, Araujo IS, Gardner T, Peres C. The value of primary, secondary and plantation forests for fruit-feeding butterflies in the Brazilian Amazon. J Appl Ecol 2007; 62: 343-64.

[37] Cattanio JH, Anderson A, Rombold JS, Nepstad D. Phenology, growth, and root biomass in a tidal floodplain forest in the Amazon estuary. Rev Brasil Bot 2004; 27 (4): 703-12.

[38] Hashimoto C, Suzuki S, Takenoshita Y, Yamagiwa J, Basabose KA, Furuichi T. How fruit abundance affects the chimpanzee party size: a comparison between four study sites. Primates 2003; 44: 7781.

[39] White LJT. Patterns of Fruit-Fall Phenology in the Lope Reserve, Gabon. J Trop Ecol 1994; 10 (3): 289-12.
[40] Dunham KM. Phenology of Acacia albida trees in Zambezi riverine woodlands. Afr J Ecol 1991; 29 (2): 118-29.

[41] Blake S. The Ecology of Forest Elephant Distribution and its Implications for Conservation. PhD Thesis. University of Edinburgh, United Kingdom 2002.

[42] Walsh PD, White LJT. What will it take to monitor forest elephant populations? Conserv Biol 1999; 13(5): 1194-202.

[43] Walsh PD, Thibault M, Mihindou Y, Idiata D, Mbina C, White LJT. A statistical framework for monitoring forest elephants. Nat Res Mod 2000; 13(1): 89-134.

[44] Walsh PD, White LJT, Mbina C, et al. Estimates of forest elephant abundance: Projecting the relationship between precision and effort. J Appl Ecol 2001; 38 (1): 217-28.

[45] Takenoshita Y, Yamagiwa J. Estimating gorilla abundance by dung count in the northern part of Moukala-Doudou National Park, Gabon. Afr Stud Monogr Suppl 2008; 39: 41-4.

[46] White LJT, Rogers MER, Tutin CEG, Williamson EA, Fernandez M. Herbaceous vegetation in different forest types in the Lopé Reserve, Gabon: implications for keystone food availability. Afr J Ecol 1995; 33: 124-41.

[47] White LTJ, Rogers ME, Tutin CEG, Williamson EA. Herbaceous vegetation in different forest types in Lopé Reserve, Gabon: implications for keystone food availability. Afr J Ecol 1995; 33: 124-41.

[48] Boubli JP, Eriksson J, Wich S, Hohmann G, Fruth B. Mesoscale transect sampling of trees in the Lomako-Yekokora interfluvium, Democratic Republic of Congo. Biodivers Cons 2004; 13: 2399-17.

[49] Upton G, Cook I. Oxford dictionary of statistics. Oxford: Oxford University Press 2004.

[50] Kent M, Coker P. Vegetation description and analysis: A practical approach. New York: John Wiley \& Sons 1994.

[51] Reinartz GE, Inogwabini BI, Mafuta N, Lisalama WW. Effects of forest type and human presence on bonobo (Pan paniscus) density in the Salonga National Park. Intl J Primatol 2006; 27 (2): 603-34.

[52] Malenky RK, Stiles EW. Distribution of terrestrial herbaceous vegetation and its consumption by Pan paniscus in the Lomako forest, Zaire. Am J Primat 1991; 23: 153-69.

[53] Cowlishaw G, Dunbar R. Primate conservation biology. Chicago: The University of Chicago Press 2000.

[54] Walker EP, Warnick F, Lange KI, et al. Mammals of the world, Volume II. Baltimore: The Johns Hopkins University Press 1964.

[55] Vaughan TA. Mammalogy. $2^{\text {nd }}$ ed. Philadelphia: Saunders Company 1978 .

[56] Inogwabini BI. Factors affecting the bonobo distribution in the Lake Tumba Swamp Forests. PhD Thesis, University of Kent at Canterbury, United Kingdom, in preparation.

[57] Horn, AD. A preliminary report on the Ecology and behavior of the Bonobo chimpanzee (Pan paniscus Schwarz 1929) and a reconsideration of the evolution of the chimpanzee. Ph.D. Thesis. Yale University. New Haven, United States of America 1976.

[58] Idani G, Kuroda S, Kano T, Asato R. Flora and vegetation of Wamba forest, Central Zaire with reference to bonobo (Pan paniscus) food. Tropics 1994; 3(3-4): 309-332.

[59] Kano T. An ecological study of the pygmy chimpanzees (Pan paniscus) of Yalosidi, Republic of Zaire. Intl J Primatol 1983; 1 (4): 1-31.

[60] Furuichi T, Hashimoto C, Tashiro Y. Fruit availability and habitat use by chimpanzees in the Kalinzu forest, Uganda: examination of fallback food. Intl J Primatol 2001; 22(6): 929-45.

[61] Conklin-Britain NL, Knott CD, Wrangham RW. Feeding ecology of great apes. The Great Apes: Challenges for the $21^{\text {st }}$ CenturyConference proceedings. Brookfield Zoo, Chicago 2001; 167-74.

[62] Kano T, Mulavwa M. Feeding ecology of the pygmy chimpanzees (Pan paniscus) of Wamba. In The pygmy chimpanzee: evolutionary biology and behaviour; Susman RL, Ed.; New York: Plenum Press 1984; pp. 233-74.

[63] Susman RL. Positional behaviour and feeding ecology of pygmy chimpanzee (Pan paniscus): first year result of the Lomako forest pygmy chimpanzee Project. Research Reports. Nat Geo Soc 1979; 225-39.

[64] White FJ. Seasonality and Socioecology: The Importance of Variation in Fruit Abundance to Bonobo Sociality. Intl J Primatol 1998; 19(6): 1013-27.

[65] White JF. Activity budgets, feeding behaviour, and habitat use of pygmy chimpanzees at Lomako, Zaire. Am J Primat 1992; 26: 215 23. 
[66] Casimir M. Feeding ecology and nutrition of an eastern gorilla group in the Mount Kahuzi region (République du Zaire). Folia Primatol 1975; 24: 136-81.

[67] Calvert JJ. Food selection by western gorillas (G. g. gorilla) in relation to food chemistry. Oecologia $1985 ; 65$ : 236-46.

[68] Tutin CEG, Fernandez M. Foods consumed by sympatric populations of Gorilla g, gorilla and Pan t. troghdytes in Gabon: some preliminary data. Intl J Primatol 1985; 6(1): $27-43$.

[69] Jones C, Sabater Pi J. Comparative ecology of Gorilla gorilla (Savage \& Wyman) and Pan troglodytes (Blumenbach) in Rio Muni, West Africa. Bibl Primatol 1971; 13: 1-96.

[70] Schaller GB. The mountain gorilla: Ecology and behaviour. Chicago: Chicago University Press 1963.

[71] Sabater Pi J. Contribution to the study of alimentation of lowland gorillas in the natural state in Rio Muni, Republic of Equatorial Guinea (West Africa). Primates 1977; 1(18): 183-204.

[72] Hohmann G, Fowler A, Sommer V, Ortmann S. Frugivory and gregariousness of Salonga bonobos and Gashaka chimpanzees: the abundance and nutritional quality of fruit. In Feeding Ecology in Apes and other Primates; Hohmann G, Robbins M, Boesch C, Eds.; Cambridge: Cambridge University Press 2006; pp. 123-59.

[73] Tutin, CEG, Ham RM, White LJT, Harrison MJS. The primate community of the Lopé Reserve, Gabon: diets, response to fruit scarcity, and effects on biomass. Am J Primat 1997; 42: 1-24.

[74] Wrangham RW. Ecology and social relationships in two species of chimpanzees. In Ecological aspects of social evolution in birds and mammals; Rubenstein DI, Wrangham RW, Eds.; Princeton: Princeton University Press 1986; pp. 352-78.
[75] Malenky RK. Food choice in Pan paniscus. Ph.D. Thesis. State University of New York, New York, United States of America: Stony Brook 1990.

[76] Doran DM, McNeilage A, Greer D, Bocian C, Mehlman P, Shah N. Western Lowland Gorilla diet and resource availability: new evidence, cross-site comparisons, and reflections on indirect sampling methods. Am J Primat 2002; 58: 91-116.

[77] Tutin CEG, White LJT, Abernethy K, Oslily R. Station d'étude des gorilles et chimpanzés de la Lopé, Gabon-dossier de présentation. Centre International de Recherche Médicale (CIRM)/ Gabon, Wildlife Conservation Society (WCS)/New York \& Musée National d'Histoire Naturelles de Paris 1997.

[78] Carroll RW. Feeding Ecology of Lowland Gorillas (Gorilla Gorilla Gorilla) in the Dzanga-Sangha dense forest reserve of the Central African Rep Republic. Ph.D. Thesis. Yale University. New Haven: United States of America 1997.

[79] Tutin CEG, White LJT, Mackanga M. The use by rain forest mammals of natural forest fragments in an equatorial Africa savanna. Conserv Biol 1994; 5 (11): 1190-203.

[80] Inogwabini BI, Matungila B, Mbende L, Abokome M, Tshimanga WT. The great apes in the Lac Tumba landscape, Democratic Republic of Congo: newly described populations. Oryx 2007; 41(4): 532-38.

[81] White LJT. The African Rain forest: climate and vegetation. In African Rain forest: ecology and conservation; Weber W, White LJT, Vedder A, Naughton-Treves, Eds. New Haven: Yale University Press 2001; pp. 3-29.

Received: December 08, 2008 Revised: January 05, 2009 Accepted: January 18, 2009

(C) Inogwabini and Matungila; Licensee Bentham Open.

This is an open access article licensed under the terms of the Creative Commons Attribution Non-Commercial License (http://creativecommons.org/licenses/by-nc/3.0/) which permits unrestricted, non-commercial use, distribution and reproduction in any medium, provided the work is properly cited. 